\title{
SOLUTION TO OVERCOME THE BANKRUPTCY POTENTIAL OF ISLAMIC RURAL BANK IN INDONESIA
}

\author{
Abrista Devi ${ }^{1}$ \\ Irman Firmansyah ${ }^{2}$
}

\begin{abstract}
This paper investigates the direct and indirect effect of macro and microeconomics variables toward financial distress by using efficiency variable as mediator. This research used time series and monthly-published report data of Islamic Banking Statistics and Macroeconomics data. The Springate Model is used to measure financial distress through s-score, while the Data Envelopment Analysis (DEA) approach is utilized to measure Islamic rural bank's efficiency. The finding implies that the efficiency of Islamic rural bank in Indonesia is mainly caused by microeconomics variables where CAR and NPF directly have significant and negative effects on efficiency, while ROA and FDR directly have significant and positive effects on efficiency. The financial distress of Islamic rural bank in Indonesia is mainly caused by micro and macroeconomics variables where CAR and SIZE directly have significant and positive effects on financial distress score, while NPF and Exchange rate directly have significant and negative effects on efficiency. Efficiency has a strong role on mediating the effect of microeconomics variables toward financial distress score of Islamic rural bank.
\end{abstract}

Keyword: Efficiency, Financial Distress, Islamic Rural Banks.

JEL Classification: D10, E42, C14

Received : September 17, 2017

Revised : April 17, 2018

Accepted : May 15, 2018

1. Lecturer, Ibn Khaldun University of Bogor. Indonesia, Corresponding author: abristasmart@gmail.com.

2. Lecturer, Siliwangi University Indonesia. Indonesia, Email: irmanfirmansyah@ unsil.ac.id. 


\section{INTRODUCTION}

To maintain the sustainability of economic growth in Indonesia, financial system stability must be kept properly. There are various ways used to maintain financial stability, one of them is keeping the sustainability of banking industry. Therefore, it needed earlier information regarding whether the bank is in a healthy or bankruptcy state. Earlier detector is also needed to identify the first information and also followed by finding the factors affecting the bankruptcy of the firm. There are two types of banks in Indonesia, namely conventional bank and Islamic bank. Both banks are common bank and rural bank. In case of Islamic bank, the bank is divided into three categories: Islamic bank, Islamic rural bank and Islamic unit business bank.

Many of previous studies on early detection of bankruptcy on Islamic banks only focus on the Islamic commercial banks. Therefore, this study is intended to focus on Islamic rural bank in Indonesia. Aside from the lack of study on Islamic rural bank, another reason for undertaking the study is the direct reach out of the rural bank to Small, Micro and Medium Enterprises. The majority of businesses in Indonesia are small-micro-medium business. Hence, Islamic rural bank has to keep their financial stability in order to avoid from financial distress. The management of Islamic rural bank is also suggested to minimize the risk of bankruptcy and become the intermediary from the poor to the rich.

There are many models used to analyze the potential of bankrupt of a firm or financial industry. The most important thing is implementing the proper model for banking with the high accuracy. One of the proper models that can be adopted is Springate model. The Springate model is more frequently used to predict the bankrupt in the several countries, because of the Springate model has high accuracy. Therefore, Springate model will be used in this study. Some researchers conclude that Springate model is a proper model to predict bankruptcy (Husein and Pambekti, 2014; Imanjadeh et al., 2011; Rahnamai et al., 2010; Yahhoubnejad and Sheikhi, 2009).

Another important factor is finding the determinant of bankruptcy of Islamic rural bank through internal and external condition effects. Internal condition is the one that can be managed by the bank, while the external condition such as macroeconomic variables is beyond the bank's control. Thus, special attention must be given to the internal factors. However, external control is required to identify early in order to prepare early warning to face existing risk condition.

There are internal factors of Islamic rural bank which are predicted to cause bankruptcy (financial distress), namely CAR (Santoso 1996; Almilia and Herdiningtyas 2005), liquidity (Altman, 1968; Deakin, 1976; Tarmizi and Kusuno, 2003), NPL/NPF(Almilia and Herdiningtyas, 2005; Rahmania and Hermanto, 2014), profitability (Almansour, 2015; Altman, 1968; Beaver, 1966; Zeitun et al., 2007), asset (Tesfamarian, 2014; Hidayat and Firmansyah, 2017), whereas the external factors consist of interest rate (Dzumahir, 2007; Ressy, 2016), exchange rate (Dzumahir, 2007; Ressy, 2016), and inflation (Dzumahir, 2007; Ressy, 2016).

Other important factor that must be taken care of by Islamic rural bank in order to ensure its financial stability is efficiency. As intermediary institutions, management is urgently to know the internal condition regarding to the operational condition. Obviously, the outflow cost must be utilized properly to obtain the 
maximum revenue. This matter indicated that bank management has been able to operate bank properly and expected to separate from bankrupt condition.

This study employed Data Envelopment Analysis (DEA), a non-parametric approach to analyze the efficiency of Islamic rural bank. Ascarya et al. (2008) stated that the strength of non-parametric approach is no need assumption of production function form to create its production frontier, and then the mistake in production function specification can be eliminated. DEA is a tool used in research methodology of finding the efficiency and productivity value from various input and output factors (Talluri, 2000). So, DEA will calculate the entire input factors used by Islamic rural bank using output comparison which is obtained from intermediary approach. Some efficiency scholars used DEA method (Al-Delaimi and Al-Ani, 2006; Ascarya et al., 2008; Firmansyah and Nasrulloh, 2015; Firmansyah and Nasrulloh, 2016).

The next step is testing the role of efficiency in order to minimize the risk of Islamic rural bank bankruptcy by using mediating analysis technique as a mediator between independent variables factors (microeconomics and macroeconomics) which affects the financial distress of Islamic rural bank. Previous studies demonstrate that that there is a relationship between efficiency and financial distress (Almilia and Herdiningtyas, 2005; Kurniasari and Ghozali, 2013; Raza, 2015; Sutawijaya and Lestari, 2009). Bank efficiency will be used to minimize the risk of bankruptcy of Islamic rural bank in Indonesia.

The objectives of this study are to analyze:

1) The direct effect of micro and macroeconomics factors on efficiency of Islamic rural bank in Indonesia;

2) The direct effect of micro and macroeconomics factors on financial distress of Islamic rural bank in Indonesia;

3) The indirect effect of micro and macroeconomics factors on financial distress using efficiency as mediator variables of Islamic rural bank in Indonesia.

This study is expected to develop a model which can be used as a tool to avoid Islamic rural bank from bankrupt risk to maintain of financial system stability.

\section{LITERATURE REVIEW}

\subsection{Islamic Rural Bank}

According to the law No. 10 year 1998 about banking, rural bank is a bank which based its activities on conventional or Islamic principles in doing so provides services in payment transactions.

Generally, the main function of rural bank is business entities which is collecting and distributing the society fund. Rural bank has to be able to support the rural modernization and give financial services to low economic community/ small micro enterprises (Law No. 10 of 1998 concerning banking). Rural bank service is given mostly to the low-capital society with an informal business sector. Therefore, management and the quality of rural bank's administration need to be improved. The improvement not only regarding to the rural bank development itself, but also the growth of real sector from informal sector, which is a big part of economic society (Septianto and Tatik, 2010). 
Operational system of Islamic rural bank is run based on profit and lost sharing concept. It means that the revenue earned by the funding customer is fluctuated comply with the revenue obtained by the bank side. Higher revenue of the bank will give higher revenue to the customer. Bank with Islamic principle is developed based on the separate of temporal aspect and religion aspect is not allowed. This principle obviously requires to shariah compliance as a basic from all life aspect. Shariah compliance not only required for worship to Allah, but also in every business transaction.

\subsection{Financial Distress}

Bankrupt is a firm condition when the firm's funds are insufficient to run its business. According to the Bankruptcy Law No. 4 of 1998, a debtor having two or more creditors and failing to pay at least one debt which has matured and become payable, shall be declared bankrupt through a Court decision, either at his own petition or at the request of one or more his creditors. Bankrupt analysis is conducted to obtain the early symptoms of bankruptcy. If the symptom of bankruptcy is getting closer, management could be able to do some corrections. So, the creditor and shareholder can prepare to solve the bad possibility things (risk occurred).

The sign of bankruptcy in this study is calculated by using accounting data. The lightest financial difficulties may be indicated from liquidity problem, and the bankruptcy statement is being the heaviest financial difficulties. There are some indicators which can be used to detect bankruptcy. To name a few, cash flow analysis and financial report are two of the indicators which can be employed. The former can predict the current and future states of the firm, while the latter can predict the bankruptcy with the assumption that financial variables distribution of the company experiencing financial difficulties. If some variables are used to predict, the possibility of mutually incompatible result will be obtained. To solve this weakness, this study will use multivariate prediction method.

\subsection{Bank Internal Factor as Islamic Rural Bank Bankruptcy Predictors}

\subsubsection{Capital Adequacy Ratio}

Capital adequacy ratio (CAR) is also known as Capital to Risk (Weighted) Assets Ratio is the bank's ability to cover the possibility risk in credit or securities transaction. High CAR will help the firm avoid bankruptcy. CAR expresses the number of total asset which contain risk funded from their capital. Some researchers proved the relationship between CAR ratio with bankruptcy prediction (Almilia and Herdiningtyas, 2005; Rahmania and Hermanto, 2014).

\subsubsection{Profitability}

Profitability is a ratio used to measure the bank's effectiveness to gain profit. It is not only used as a financial performance measurement, but also important to pretend capital source by considering profit. Profitability analysis technique involves the relationship between current posts in income statement to obtain the 
measurement able used as indicators for efficiency valuation and the ability of a bank to generate earnings. Therefore, this analysis technique is commonly stated by income statement analysis.

The common analysis technique to valuate profitability is Return on Asset (ROA). It is an indicator of how profitable a company is relative to its total assets. ROA also gives an idea as to how efficient management is at using its assets to generate earnings. ROA is calculated based on the comparison of profit before tax and total asset. Bank with relatively huge total asset will have better performance because they have relatively huge total revenue as a result of product sales increasing. If the profitability ratio is getting higher than it show the relationship between profitability and financial distress condition. This statement is supported by some previous studies (Almansour, 2015; Altman, 1968; Beaver, 1966; Rahmania and Hermanto, 2014; Zeitun et al., 2007).

\subsubsection{Non-Performing Financing}

Non-Performing Financing (NPF) is a ratio that can assess the percentage of NPF in Islamic bank. A high NPF decreased the profitability rate. The decreasing of bank profitability will affect the bank capability to expand their financing business and financing performance is also decreasing. Financing risk which is accepted by the bank is being one of bank business risk. Financing risk is affected from unpaid debt which is given by the bank, or investment conducted by the bank side (Muhammad, 2005).

The increasing NPF rate will increase the number of "allowance for possible losses on earning assets" that need to be formed by the bank. If this matter is continuing happen, it will decrease bank capital, because NPF can affect to the bank number of capital. Logically, the increasing of NPF value automatically will decrease the number of financing. One of another implication for the bank is as a result of cost problem, where bank will lose the opportunity to generate income and the number of financing, so the profit obtained will decrease. This condition will make Islamic bank to the potency of bankrupt closer. Some previous study obtained regarding to the relationship of NPL/NPF and the potency of bankrupt (Almilia and Herdiningtyas, 2005; Rahmania and Hermanto, 2014).

\subsubsection{Liquidity}

Loan to deposit ratio (LDR) shows the percentage of a bank's loans that the bank funds with its deposits. Banks need to maintain a certain amount of liquidity to handle withdrawals and conduct business. The loans bank issue occupies a large amount of their capital. Islamic banking is not familiar with credit term (loan), but financing. Bankers have perfect agreement regarding to the cut off LDR is about $80 \%$. Tolerance cut off is between $85 \%-100 \%$. However, Bank of Indonesia stated that a healthy bank is when the LDR value $<110 \%$.

Islamic bank liquidity is measured by the FDR ratio, the ability of Islamic bank to refund customer's banking deposits. Therefore, if Islamic bank is able to provide the fund needed, the liquidity of the bank is in a good condition and far from bankruptcy risk. Hence, it can be stated that there is a relationship 
between liquidity and financial distress (Altman, 1968; Deakin, 1976; Hidayat and Firmansyah, 2017; Tarmizi and Kusuno, 2003).

\subsubsection{Size}

Size of a firm is a measurement of their wealth which is represented by total asset. The firm with a large total asset will have strong financial position, vice versa. Large number of total asset, the firm is expected to have the capability to pay their debt in the future, so the company can avoid from financial problem especially bankruptcy. Therefore, it is predicted that the company with a large number of asset will further from bankruptcy potential. Some previous study supported the relationship between size and financial distress (Hidayat and Firmansyah, 2017; Tesfamarian, 2014).

\subsection{Bank External Factor as Islamic Rural Bank Bankruptcy Predictor 2.4.1. Inflation}

Inflation is the rate at which the general level of prices for goods and services is rising and, consequently, the purchasing power of currency is falling. Inflation happens because of uncertainty of macroeconomics of a country, the uncertainty of economics of a country will cause the society will use their fund for consumption.

The increasing of level price and the constant income also will cause the society to do not have exceed fund to save or invest. This condition will cause the society to experience less fund to consume, so it will affect to the credit rate (financing) distributed by the bank. So, the inflation also can cause to the decreasing of bank performance. If it is happening continuously, potency of bankruptcy will occur. Some previous study supported the relationship between size and financial distress (Dzumahir, 2007; Ressy, 2016).

\subsubsection{Exchange Rate}

Exchange rate is the price of a nation's currency in terms of another currency. An exchange rate thus has two components, the domestic currency and foreign currency, can be quoted either directly or indirectly. In a direct quotation, the price of a unit of foreign currency is expressed in terms of the domestic currency. In an indirect quotation, the price of a unit of domestic currency is expressed in terms of the foreign currency.

Exchange rate represents the economic stability of a country. In this study, exchange rate used is rupiah (IDR) toward dollar (US). If the currency of rupiah toward dollar is appreciation, it indicates the economic condition of Indonesia country in a good condition. The appreciation of rupiah toward dollar will encourage the increasing of company activity because it was not burdened with the weight of rupiah exchange rate especially for the firm who relies on import raw materials. Therefore, if rupiah exchange rate toward dollar is appreciated, customer will easily to pay their debt. This condition actually will give benefits to the bank because they can increase their profit, so the bank will avoid from the potency of bankruptcy. Some previous study supported the relationship between exchange rate and financial distress (Dzumahir, 2007; Ressy, 2016). 


\subsubsection{BI rate}

The BI rate is the policy rate reflecting the monetary policy stance adopted by Bank Indonesia and announced to public. BI rate is the main determinant of revenue and risk of the bank. Conventional bank will determine the interest rate by following the level of BI rate, it means that conventional bank have guidelines in order to save their financial condition in the middle of uncertainty of economic condition. In contrast to Islamic bank, where Islamic bank determine the profit based on profit and lost sharing, so it is urgently needed good management system to solve the existing risk. Furthermore, it is also required the study conducted regarding to the relationship between BI rate and financial performance of Islamic bank, considering Islamic bank is under Bank of Indonesia control.

Despite of that condition, Indonesian people still compare between profit and risk in case of choosing whether conventional bank or Islamic bank, in another word Indonesian people is rational economic type customer. Therefore, Islamic bank is affected by the regulation of Bank Indonesia toward their operational activity. This is the sign that BI rate could affect to Islamic bank for the long term and will affect the financial distress. Some previous study supported the relationship between BI rate and financial distress (Dzumahir, 2007; Ressy, 2016).

\subsection{Efficiency}

For the business entity, efficiency is the most important matter to keep their operational activity run properly. Efficiency concept is generally defined as doing the thing right. This concept also generally related on how the firms achieve their goal. Therefore, efficiency concept generally measured by the cost side as input and profit (revenue) side as output. Business entity is always tries to decrease the level of cost into the minimum level, to produce the maximum level of output.

There are two types of efficiency in the economic theory: economic efficiency and technical efficiency. Economic efficiency represents macro condition, while technical efficiency represents micro condition. Efficiency measurement technique is a tool to identify the operational relationship from input process to be output. In order to measure the level of technical efficiency, generally used Data Envelopment Analysis (DEA). The term of efficiency in DEA most commonly refer to the relationship of input and output of a unit business.

Efficiency which is measured by DEA will be tested its role toward the financial distress of Islamic rural bank, considering the relationship between efficiency and financial distress has been proved by some previous studies (Almilia and Herdiningtyas, 2005; Kurniasari and Ghozali, 2013; Raza, 2015; Sutawijaya and Lestari, 2009). 


\subsection{Research Model Development}

The research model is represented by the following figure:

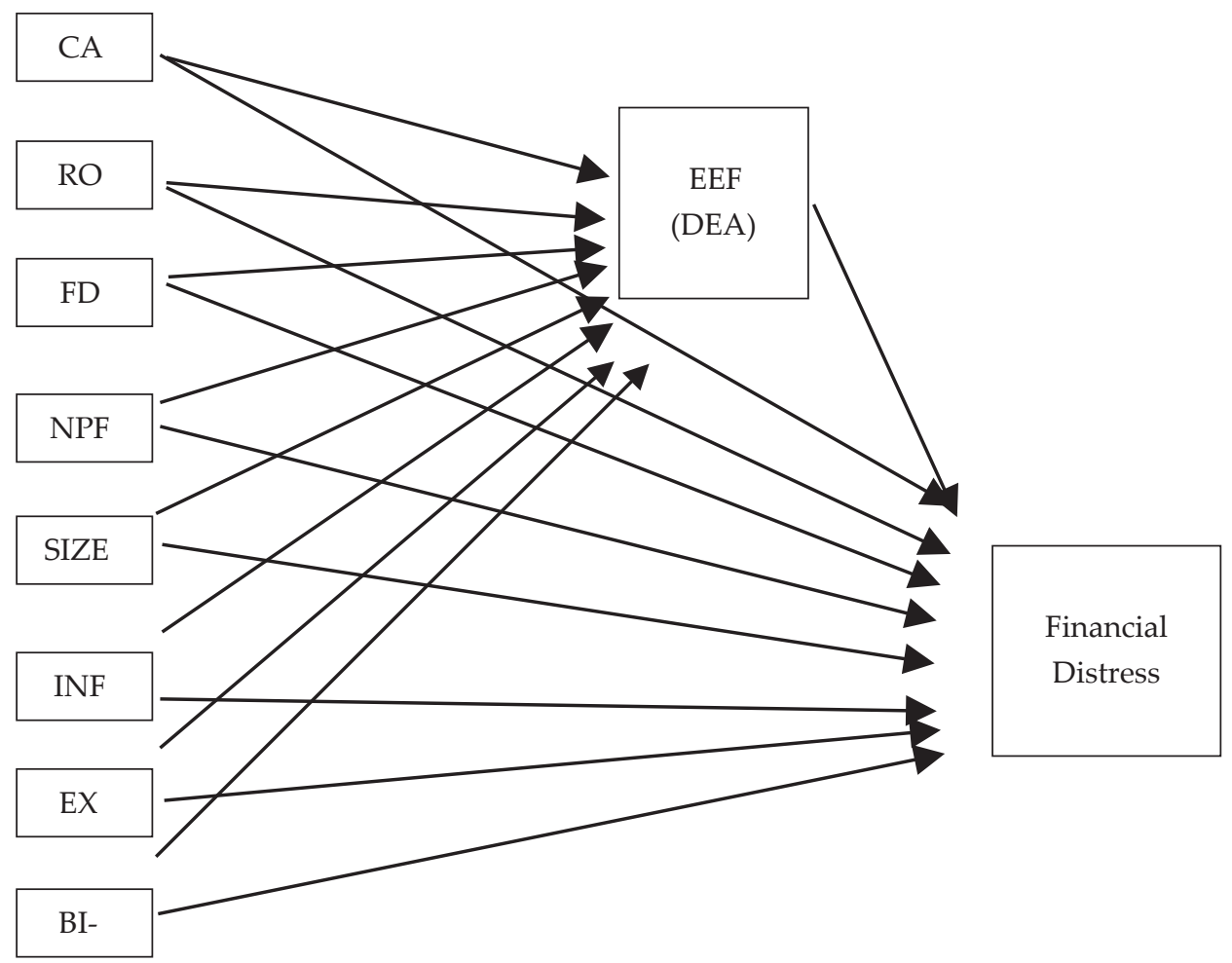

Figure 1.

Research Conceptual Framework

\section{METHODOLOGY}

\subsection{Data}

This study is a quantitative study using secondary data. Secondary data is obtained from published data acquired from several sources, namely 1) Internal data of Islamic rural bank which is obtained from Islamic banking statistic. Islamic banking statistic is regularly published by Bank Indonesia and Financial Services Authority (OJK; Otoritas Jasa Keuangan). The data is accumulated data from the entire of Islamic rural bank in Indonesia. Therefore, this research is not performed to each of Islamic rural bank, 2) External data which is obtained from Statistic Centre (Badan Pusat Statistik / BPS) and Bank Indonesia (BI). 


\subsection{Data Analysis Method}

\section{a. Analysis of Bankruptcy Potential using Springate Model}

The following formula is a model which was developed by Springate to predict the bankruptcy of the firm:

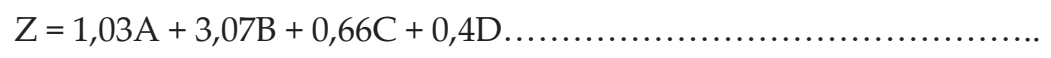

Where:

$$
\begin{aligned}
& \mathrm{A}=\frac{\text { WorkingCapital }}{\text { TotalAsset }} \\
& \mathrm{B}=\frac{\text { NetProfitBeforeInterest }}{\text { TotalAsset }} \\
& \mathrm{C}=\frac{\text { NetProfitBeforeTaxes }}{\text { CurrentLiabilities }} \\
& \mathrm{D}=\frac{\text { Sales }}{\text { TotalAsset }}
\end{aligned}
$$

The firm classification is using s-score, it the $Z \geq 0,862$ means that the firms that were not potentially bankrupt, while if the score of $Z<0,862$ it is classified as unhealthy company and potentially bankrupt.

\section{b. Efficiency Analysis with Data Envelopment Analysis (DEA)}

Charnes, Cooper and Rhodes (1978) developed DEA by method of constant return to scale (CRS) and then developed by Banker, Charnes and Cooper by method of variable return to scale (VRS) and finally popular with CCR (Charnes-CooperRhodes) and BCC (Banker-Charnes-Cooper) model. DEA is procedure, specifically formulated to measure relative efficiency in a bank which is using multiple input and output.

Islamic Banking Efficiency measurement in this research is done by counting the ratio of output and input. Data Envelopment Analysis (DEA) will compute the period of Islamic Bank by using input $n$ to produce different output $m$. Efficiency in every period of Islamic Bank is computed by linier programming by maximizing weighted total output from period of Islamic Banks. The restricted of total amount of weighted input must be equal to 1 to all bank, and total output reduced by weighted total input must be less or equal to 0 . It means that all period of Islamic Bank is considered as well as or below the frontier performance reference (Komaryatin, 2006; Tanjung \& Devi, 2013).

Data Envelopment Analysis (DEA) will compute the value of $h s$, where $h s$ is the efficiency score for each period of Islamic bank. DEA maximize the value of $h s$, where $h s$ is sum multiplication between weight of output $i$ and total output $I$ in $s$ period of Islamic Bank.

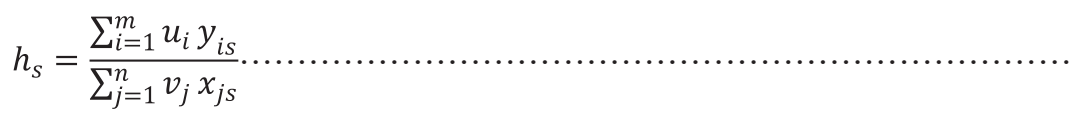


Where:

hs = bank efficiencys

$m$ = observed output banks

$n=$ observed input banks

$y_{\text {is }}=$ total output $i$ produced by banks

$x_{j s}=$ total input $j$ used banks

$u_{i}=$ weighted output produced by bank s

$v_{j}=$ weighted input $j$ given by bank $s$ and $i$ computed from 1 to $m$ and $j$ computed from 1 to $n$

The formulation above shows the use of one input variable and one output variable. Efficiency ratio $(h s)$ to be maximized by restricting as follows (Sutawijaya and Lestari, 2009):

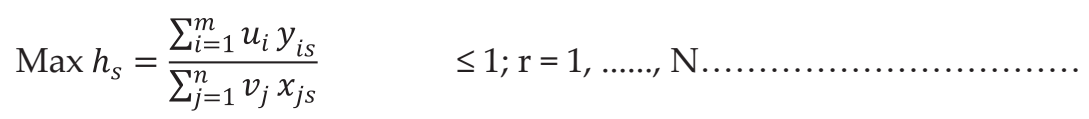

Where $u_{i}$ and $v_{j} \geq 0$

From the formulation above, where $\mathrm{N}$ represents total amount of bank in samples and $r$ is the type of bank sampled in this research. Inequality of first formula explained that the ratio of others DMU no more than 1 , meanwhile second formula weighted non-negative (positive). Ratio value might be varying from 0 to 1 . The bank will be considered as efficient unit only if a ratio value nearly 1 or $100 \%$, otherwise if a ratio value nearly 0 shows bank efficiency is getting lower.

In DEA, every bank could define their weight and ensure that the chosen weighting will result the best performance measurement (Sutawijaya and Lestari, 2009). Banxia Frontier Analyst 3 programs used to analyze technical efficiency in this research. In order to obtain efficiency value, this study employed two variables of input consist of Current Debt and current asset, and two variables of output consist of profit before tax and total revenue.

\section{c. Path Analysis}

Path analysis is used to determine the effect of independent variables (internal and external Islamic rural bank) toward the bankruptcy risk of Islamic rural bank (dependent variables) and to test the role of efficiency as mediator variables between independent variables and dependent variables. LISREL program is used to analyze path analysis.

The equations of path analysis are as follows:

1. The first equation model (the effect of internal and external factors of Islamic rural banks toward efficiency)

$\mathrm{EFF}=\mathrm{a}+\mathrm{b}_{1} \mathrm{CAR}+\mathrm{b}_{2} \mathrm{ROA}+\mathrm{b}_{3} \mathrm{NPF}+\mathrm{b}_{4} \mathrm{FDR}+\mathrm{b}_{5} \mathrm{SIZE}+\mathrm{B}_{6} \mathrm{INF}+\mathrm{b}_{7} \mathrm{EXC}+$

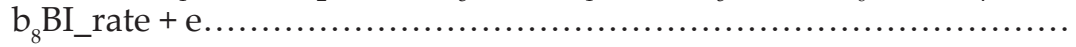

2. The second equation model (the effect of internal, external factors and efficiency of Islamic rural banks toward financial distress). 
$\mathrm{FD}=\mathrm{a}+\mathrm{b}_{1} \mathrm{CAR}+\mathrm{b}_{2} \mathrm{ROA}+\mathrm{b}_{3} \mathrm{NPF}+\mathrm{b}_{4} \mathrm{FDR}+\mathrm{b}_{5} \mathrm{SIZE}+\mathrm{B}_{6} \mathrm{INF}+\mathrm{b}_{7} \mathrm{EXC}+$

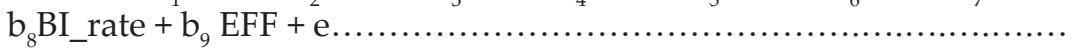

Where:
$\mathrm{CAR}=$ Capital Adequacy Ratio
ROA = Return on Asset
NPF $=$ Non-Performing Financing
FDR = Finance to Deposit Ratio
SIZE $=$ Total Asset (Ln Total Asset)
INF $=$ Inflation
EXC = Exchange rate Rupiah toward US Dollar
$\mathrm{BI}$ rate $=$ Interest rate of Bank Indonesia
$\mathrm{EFF}=$ Efficiency
$\mathrm{e}=$ error

\subsection{Empirical Model}

There are three variables main variables are used in this study, namely:

a. Dependent Variable, consist of Financial distress which is calculated from Springate model.

b. Independent Variable, consist of factors affecting to financial distress, namely:

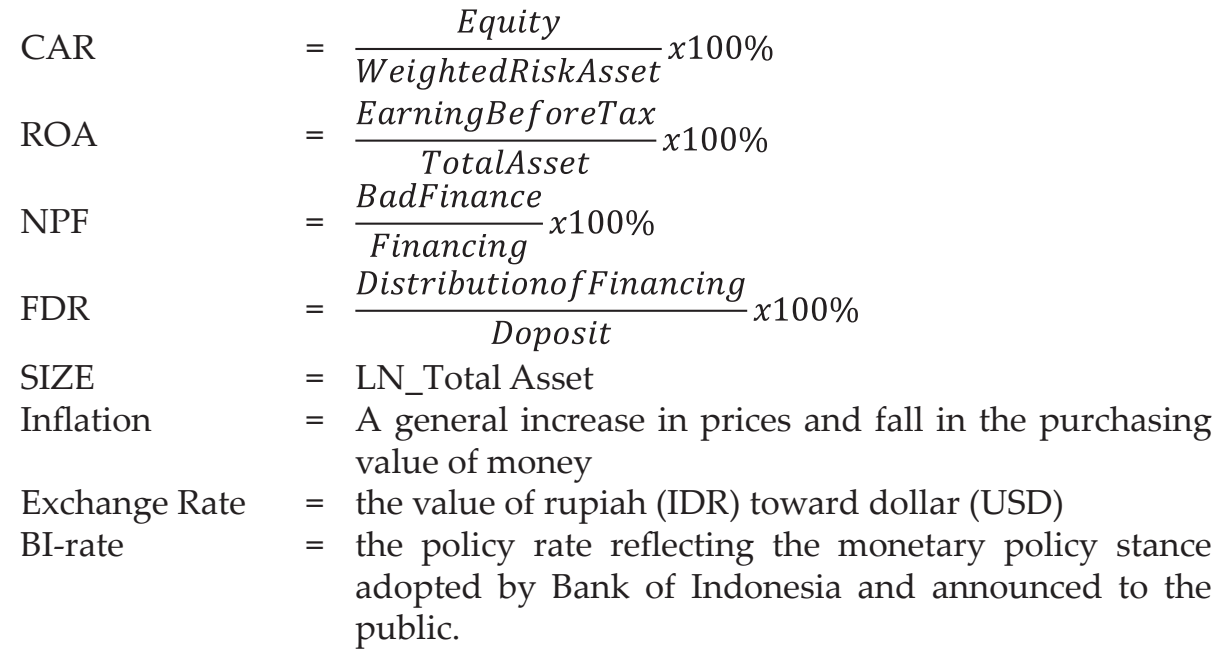

c. Mediator Variable is efficiency which is obtained after efficiency analysis using non-parametric method. In order to analyze efficiency needed two kinds of variables, namely input variable (consist of current asset and current debt) and output variable (consist of profit and total revenue).

\section{RESULT AND FINDING}

\subsection{Descriptive Statistics Analysis}

Based on the results of descriptive statistics in Table 1, it can be concluded that the lowest value of CAR in Islamic Rural Bank in Indonesia is 14.88, while the 
maximum value is 33.25 with mean value is 23.40 . The lowest CAR value of Indonesia's Islamic Rural Bank occurred on November 2011 and the highest value occurred on February 2010. The lowest value of ROA in Islamic Rural Bank in Indonesia is 1.75 , while the maximum value is 5.00 and followed by mean value is 2.65. The lowest ROA value of Indonesia's Islamic Rural Bank occurred on October 2011 and the highest value occurred on December 2009.

The lowest value of ROE in Islamic Rural Bank in Indonesia is 9.61, while the maximum value is 25.45 and followed by mean value is 17.61 . The lowest ROE value of Indonesia's Islamic Rural Bank occurred on March 2011 and the highest value occurred on April 2013. The lowest value of NPF in Islamic Rural Bank in Indonesia is 2.74 occurred on November 2011, while the maximum value is 10.99 occurred on August 2016 and followed by mean value is 7.60. The lowest value of FDR in Islamic Rural Bank in Indonesia is 91.97 occurred on January 2011, while the maximum value is 139.96 occurred on August 2010 and followed by mean value is 123.67 .

Microeconomics data presents similar findings, in which the lowest of Islamic rural bank financial performance occurred in 2011. However, the Islamic rural bank achieved the lowest NPF value in the same year. This can be traced back to the small number of financing distributed by the Islamic Rural Bank in 2011. This condition is in-line with Islamic rural bank development condition from 2011 to 2012. Total assets of Islamic banks decreased from IDR 117.510 billion in 2011 to IDR116.871 billion on February 2012.

Table 1.

Results of a Descriptive Analysis of the Variables

\begin{tabular}{|c|c|c|c|c|c|}
\hline Variables & & Mean & Std. Deviation & Minimum & Maximum \\
\hline \multirow{4}{*}{$\begin{array}{c}\text { Micro } \\
\text { economics }\end{array}$} & CAR & 23.40 & 3.58 & 14.88 & 33.25 \\
\hline & $\mathrm{ROA}$ & 2.65 & 0.58 & 1.75 & 5.00 \\
\hline & NPF & 7.60 & 1.79 & 2.74 & 10.99 \\
\hline & FDR & 123.67 & 10.64 & 91.97 & 139.96 \\
\hline \multirow{3}{*}{$\begin{array}{c}\text { Macro } \\
\text { economics }\end{array}$} & INF & 5.41 & 1.64 & 2.78 & 8.79 \\
\hline & $\begin{array}{l}\text { EXCHANGE } \\
\text { RATE }\end{array}$ & 9.31 & 0.15 & 9.11 & 9.59 \\
\hline & BI RATE & 6.71 & 0.66 & 5.75 & 7.75 \\
\hline \multirow{5}{*}{$\begin{array}{c}\text { Springate's } \\
\text { Model }\end{array}$} & TOTAL ASSET & 5151697.14 & 2026701.02 & 2123581.00 & 9157801.00 \\
\hline & $\begin{array}{l}\text { CURRENT } \\
\text { ASSET }\end{array}$ & 4848006.70 & 1954172.07 & 30614.00 & 8631850.71 \\
\hline & $\begin{array}{l}\text { CURRENT } \\
\text { DEBT }\end{array}$ & 3155814.97 & 1325094.47 & 52271.00 & 5823963.74 \\
\hline & PROFIT & 57354.15 & 36059.04 & 791.00 & 159002.81 \\
\hline & REVENUE & 276332.34 & 265403.62 & 920.00 & 976450.37 \\
\hline
\end{tabular}

Source: Data processed

While the highest financial performance of Islamic rural bank occurred in various years, such as the highest value of CAR is occurred on February 2010, while the highest value of ROA is occurred on December 2009, and the highest 
value of FDR occurred on August 2010. The highest value of NPF is occurred on August 2016. The highest value of NPF is also followed by the increasing of the number of financing in Indonesia's Islamic banking. The lowest inflation occurred in December 2009, but the highest inflation occurred in August 2014. The lowest condition of exchange rate is occurred on September 2015 where rupiah down into IDR 14.387 if compared to previous month (October) was IDR 13.417. The highest rate of BI rate occurred on December 2014 and continued until January 2015. The mean value of CAR is 23.40 , means that the capital adequacy exceeded the minimum $8 \%$ set by Basel Committee. Obviously, it would be good news for the development of Islamic rural bank in Indonesia.

\subsection{Direct Effect of Macro and Microeconomics to the Efficiency}

CAR directly has a significant negative effect on the efficiency of Islamic rural bank in Indonesia. The result of this study is supported by previous research from Sutrisno (2016) where the capital risk measured by CAR showing a negative influence and exhibited significantly to efficiency. Furthermore, Sutrisno (2016) explained that high CAR reduced the chance to be played in the financing, and resulting in decreased profitability. Some studies also found a significant effect of CAR on the performance of Islamic banks in Indonesia (Akhtar et al., 2011; Irwan, 2017 ;Ruslim, 2012). CAR demonstrated the ability of banks to disburse very low, thus, emerging so many unemployed equities (Sutrisno 2016).

ROA directly has significant positive effect on efficiency of Islamic rural bank in Indonesia. Return on Asset is contributing to the level of efficiency of Islamic rural bank. It showed that one financial performance need to achieve by Islamic rural bank to increase its efficiency level is ROA. The result of this study is supported by research before (Irwan, 2017) that ROA of Islamic rural banks in Indonesia partially and jointly has positive and significant influence toward bank performance.

NPF directly has significant negative effect on efficiency of Islamic rural bank in Indonesia. The result of this study is supported by research before (Akhtar et al., 2011; Irwan, 2017) were found a significant negative effect NPF to the performance of banks. It confirms the findings of Sriyana that increasing in NPF will reduce Islamic banks profit (Sriyana, 2015).

Table 2.

Results of a direct effect of Macro \& Microeconomics to the Efficiency

\begin{tabular}{lcrl}
\hline \multicolumn{1}{c}{ Hypothesis } & Loading Factor & t-Value & \multicolumn{1}{c}{ Summary } \\
\hline CAR - EFF & -0.94 & -4.19 & Negative - Significant \\
ROA - EFF & 0.61 & 2.26 Positive - Significant \\
NPF - EFF & -0.79 & -2.66 Negative - Significant \\
FDR - EFF & 0.72 & 3.87 Positive - Significant \\
SIZE - EFF & -0.19 & -0.96 Negative - Insignificant \\
INF - EFF & -0.02 & -0.12 & Negative - Insignificant \\
EXC RATE - EFF & 0.52 & 1.77 Negative - Insignificant \\
BI RATE - EFF & -0.27 & -1.45 & Negative - Insignificant \\
\hline
\end{tabular}


FDR directly has significant positive effect on efficiency of Islamic rural bank in Indonesia. The result of this study is supported by research before (Irwan, 2017) that FDR are slightly has positive influence on bank performance in Islamic rural bank of Indonesia. FDR measures the bank's liquidity that shows the ability of the bank to fulfil credit demand by using bank's assets (Setiawan and Putri, 2013). The higher credit tends to create the greater income (Sriyana, 2015). FDR is employed as output in efficiency approach. An increase in FDR will cause an increase in the efficiency of Islamic Rural Bank in Indonesia. It is closely related to the main function of Islamic rural bank itself in giving the financing for more extended micro-business segment that hasn't covered by Islamic bank.

From the several microeconomics variables, CAR is the highest coefficient among the determinant microeconomics variables used in this research that affect efficiency of Islamic rural bank in Indonesia, while ROA is the weakest coefficient that affect to efficiency of Islamic rural bank. The finding implies from this subanalysis is the most determinant variables effect to efficiency is coming from internal aspect (such as CAR, ROA, NPF, and FDR), and none of external variables are affecting to the efficiency of Islamic rural bank in Indonesia.

\subsection{Direct Effect of Macro and Microeconomics to the Financial Distress}

CAR directly has significant positive effect on financial distress of Islamic rural bank in Indonesia. The result of this study is supported by previous studies (Almilia and Herdiningtyas, 2005; Mongid, 2015; Santoso, 1996). Islamic rural bank is suggested to manage their CAR ratio optimally to avoid from bankruptcy. NPF directly has significant negative effect on financial distress of Islamic rural bank in Indonesia. Financial distress is measured using Springate Model and then calculating Z-score as a proxy of financial distress. So, it can be concluded that higher s-score describe less potential of company's bankruptcy and do so otherwise. The result of this study is in-line with the hypothesis the high of NPF value will give the high potential of company's bankruptcy.

The result of this study is supported by previous researches (Mongid, 2015; Rahmania and Hermanto, 2014) stated that NPF is being a measure of bank loan quality. It means that the increasing of NPF would affect to the increasing of loan default as well as its effects on liquidity position. It confirms the findings of Smith and Gunther (2017) that financial distress is a more significant predictor of poverty rather than microcredit. The finding of this study is in-line with the nature of business of Islamic rural bank in Indonesia which gives the financing for micro business. In order to reach good financial distress, Islamic rural bank is suggested to manage their NPF value very well.

Size directly has significant positive effect on financial distress of Islamic rural bank in Indonesia. Firm size is indicated by the number of assets which is also could affect to the banks profit. Therefore, greater asset that owned by Islamic rural bank will affect to the lower potential of bankruptcy. The result of this study supports previous studies (Hidayat and Firmansyah, 2017; Sutrisno, 2016), which found that the greater ability of banks to provide financing risk because they have more funds to provide the financing risk. 
A study by Zeitun (2012) also reveal that the firm size has positively affects to the performance of Islamic banks; it means that Islamic rural bank could decrease the potential of financial distress. Asset size is also important as a growing asset improves bank liquidity position. The weakness in liquidity management in the Islamic rural banking market is detected. Islamic rural bank need to set a high liquidity ratio (up to $35 \%$ ) as self-insurance to anticipate liquidity risk, then it will help Islamic rural bank to avoid bankruptcy (Mongid, 2015).

Table 3.

Results of a Direct Effect of Macro \& Microeconomics to the Efficiency

\begin{tabular}{lrrl}
\hline \multicolumn{1}{c}{ Hypothesis } & Loading Factor & \multicolumn{1}{c}{ t-Value } & \multicolumn{1}{c}{ Summary } \\
\hline CAR - FIN DISTRESS SCORE & 0.14 & 2.09 & Positive - Significant \\
ROA - FIN DISTRESS SCORE & 0.13 & 1.73 & Positive - Insignificant \\
NPF - FIN DISTRESS SCORE & -0.33 & -3.93 & Negative - Significant \\
FDR - FIN DISTRESS SCORE & -0.01 & -0.14 & Negative - Insignificant \\
SIZE - FIN DISTRESS SCORE & 1.46 & 26.69 & Positive - Significant \\
INF - FIN DISTRESS SCORE & 0.06 & 1.58 & Positive - Insignificant \\
EXC RATE - FIN DISTRESS SCORE & -0.54 & -6.67 & Negative - Significant \\
BI RATE - FIN DISTRESS SCORE & -0.05 & -1 & Negative - Insignificant \\
\hline
\end{tabular}

Source: Data processed

Exchange Rate directly has significant negative effect on financial distress of Islamic rural bank in Indonesia. The result of this study is not matching to the supporting theory which stated that the high value of exchange rate indicates the depreciation of rupiah toward dollar. It means that the depreciation of rupiah value toward dollar will increase the risk of financial distress. The reason from this finding is Islamic rural bank is free interest banking with micro financing. Islamic rural bank is indicated saver from inflation as well as rupiah depreciation toward dollar than conventional one. The result of this study is supported by research before that stated that Islamic banks are more resilient than conventional banks (Dzumahir, 2007; Jawadi et al., 2016; Ressy, 2016).

From several microeconomics variables, NPF is the highest coefficient among the determinant microeconomics variables used in this research that affect financial distress of Islamic rural bank in Indonesia, while CAR is the weakest coefficient that affect to financial distress of Islamic rural bank. The finding implies from this sub-analysis is the most determinant variables effect to efficiency is coming from internal variables (such as CAR, NPF and Size) and external variable (Exchange Rate).

\subsection{Direct Effect of Efficiency to the Financial Distress}

Efficiency directly has significant positive effect on financial distress of Islamic rural bank in Indonesia. The result of this study is supported by research before (Firmansyah and Nasrulloh, 2015 and Firmansyah and Nasrulloh, 2016) assert that competition within the banking industry enables efficient banks to be more 
financially stable and less likely to be distressed and thus confirms the theory that the efficient bank will lead into less potential of bankruptcy (Boone, 2008). One approved way to reach good efficiency for banking is in-charge in competition within the firms. Efficiency is one successful indicator to evaluate the firm performance. Therefore, Islamic rural bank need to achieve good efficient condition in order to avoid from the financial risk (bankruptcy).

Table 4.

Results of a direct effect of Efficiency to the Financial Distress

\begin{tabular}{crrr}
\hline Hypothesis & Loading Factor & t-Value & Summary \\
\hline EFF - FIN DISTRESS SCORE & 0.33 & 10.68 & Positive - Significant \\
\hline
\end{tabular}

Source: Data processed

\subsection{Indirect Effect of Macro and Microeconomics toward Financial Distress}

The result of indirect micro and macroeconomic effect on financial distress can be seen in Table 5. CAR indirectly through the efficiency has significantly negative effect on financial distress of Islamic rural bank in Indonesia. ROA indirectly through the efficiency has significantly positive effect on financial distress of Islamic rural bank in Indonesia. NPF indirectly through the efficiency has significantly negative effect on financial distress of Islamic rural bank in Indonesia. FDR indirectly influence the possibility of financial distress through the efficiency.

Table 5.

Results of an indirect effect of Macro and Microeconomics to the Financial Distress through Efficiency

\begin{tabular}{lrrl}
\hline \multicolumn{1}{c}{ Hypothesis } & $\begin{array}{c}\text { Loading } \\
\text { Factor }\end{array}$ & t-Value & \multicolumn{1}{c}{ Summary } \\
\hline CAR - EFF - FIN DISTRESS SCORE & -0.01 & -3.9 Negative - Significant \\
ROA - EFF - FIN DISTRESS SCORE & 0.04 & 2.21 Positive - Significant \\
NPF - EFF - FIN DISTRESS SCORE & -0.02 & -2.58 Negative - Significant \\
FDR - EFF - FIN DISTRESS SCORE & 0.01 & 3.64 Positive - Significant \\
SIZE - EFF - FIN DISTRESS SCORE & -0.01 & -0.96 Negative - Insignificant \\
INF - EFF - FIN DISTRESS SCORE & -0.01 & -0.12 Negative - Insignificant \\
EXC - EFF - FIN DISTRESS SCORE & 0.14 & 1.75 Positive - Insignificant \\
BI RATE - EFF - FIN DISTRESS SCORE & -0.02 & -1.43 Negative - Insignificant \\
\hline
\end{tabular}

Source: Data processed

The findings show that efficiency is the mediator between microeconomic variables toward financial distress in Islamic rural bank. This mediating role is not applicable for macroeconomic variables toward financial distress. This finding is supported by previous study conducted by Li (2014) which found that firms with lower efficiency have higher risks of financial distress. Financial ratio affects the financial distress through efficiency role. This finding obviously can benefit managers and owners of Islamic rural bank in Indonesia to improve the efficiency variable to generate more profits and revenue in order to avoid financial distress of a firm. 


\section{CONCLUSION}

\subsection{Conclusions}

The study examines the effect of microeconomics (CAR, ROA, NPF, FDR, and SIZE) and macroeconomics (INF, Exchange Rate, and BI Rate) variables toward financial distress through efficiency as mediating variables. Based on the findings, we formed the conclusions as follows:

1) CAR directly has significant negative effect on efficiency of Islamic rural bank in Indonesia. ROA directly has significant positive effect on efficiency of Islamic rural bank in Indonesia. NPF directly has significant negative effect on efficiency of Islamic rural bank in Indonesia. FDR directly has significant positive effect on efficiency of Islamic rural bank in Indonesia. While Size, Inflation, Exchange rate, and BI rate variable have insignificant negative effect on efficiency of Islamic rural bank in Indonesia.

2) CAR directly has significant positive effect on financial distress of Islamic rural bank in Indonesia. ROA directly has insignificant positive effect on financial distress of Islamic rural bank in Indonesia. NPF directly has significant negative effect on financial distress of Islamic rural bank in Indonesia. FDR directly has insignificant negative effect on financial distress of Islamic rural bank in Indonesia. Size directly has significant positive effect on financial distress of Islamic rural bank in Indonesia. Inflation directly has insignificant positive effect on financial distress of Islamic rural bank in Indonesia. Exchange rate directly has significant negative effect on financial distress of Islamic rural bank in Indonesia. BI rate directly has insignificant negative effect on financial distress of Islamic rural bank in Indonesia.

3) Efficiency directly has significant positive effect on financial distress of Islamic rural bank in Indonesia.

4) CAR and NPF indirectly through the efficiency has negative and significant effect on financial distress. While ROA and FDR indirectly through the efficiency has positive and significant effect on financial distress.

The findings demonstrate that CAR, Size and efficiency are variables that have an important role for Islamic rural bank to avoid from bankruptcy, while NPF is variable which causes bankruptcy. Form the macroeconomics variables, only the exchange rate variable affects the bankruptcy of Islamic rural bank. Efficiency is mediating the influence of ROA and FDR toward financial distress positively. It showed that efficiency is strongly being the mediator between ROA and FDR toward financial distress, and otherwise efficiency is negatively being the mediator between NPF toward financial distress. It means that efficiency is able to weaken the influence of NPF which increases the bankruptcy risk of Islamic rural bank. Therefore, Islamic rural bank must pay attention to efficiency condition because efficiency gives the good effect to the financial stability of Islamic rural bank in Indonesia.

\subsection{Recommendations}

a) In the future, it is expected that the management of Islamic rural bank can give more attention to the management of asset quality and efficiency, because both of which are very significant determine the financial distress. 
b) In the future, it is expected that the management of Islamic rural bank in can manage their wealth properly to reach a better financial ratio performance. This is due to the fact that most of the causes of financial distress are coming from microeconomics variables, both direct and indirect influence.

\section{REFERENCES}

Akhtar, F. M., Khizer, A., \& Shama, S. (2011). Factors influencing the profitability of Islamic bank of Pakistan. International Research Journal of Finance and Economics, $66,125-132$.

Al-Delaimi, K. S. K., \& Al-Ani, A. H. B. (2006). Using Data Envelopment Analysis to Measure Cost Efficiency With an Application on Islamic Banks. Scientific Journal of Administrative Development, 4, 23.

Almansour, B. Y. (2015). Empirical Model for Predicting Financial Failure. American Journal of Economics, Finance and Management, 1(3), 113-124.

Almilia, L. S., \& Herdiningtyas, W. (2005). Analisis Rasio CAMEL terhadap Prediksi Kondisi Bermasalah pada Lembaga Perbankan Periode 2000-2002. Jurnal Akuntansi dan Keuangan, 7(2), 131-147.

Altman, E. I. (1968). Financial Ratios, Discriminant Analysis and the Prediction of Corporate Bankruptcy. The Journal of Finance, 23(24), 589-609.

Ascarya, Yumanita, D., \& R, G. S. (2008). Analisis Efisiensi Perbankan Konvensional dan Perbankan Syariah di Indonesia dengan Data Envelopment Analysis (DEA). Jakarta: Kencana Prenada Media Group.

Beaver, W. H. (1966). Financial ratios as predictors of failure. Journal of Accounting Research, 4(3), 71-131.

Boone, J. (2008). A New way to measure competition. The Economic Journal, 118(531), 1245-1261.

Charnes, A., Cooper, W. W., \& Rhodes, E. (1978). Measuring the Efficiency of Decision Making Units. European Journal of Operation Research, 2(6), 429-440.

Deakin, E. B. (1976). Distributions of financial accounting ratios: some empirical evidence. The Accounting Review, 90-96.

Dzumahir. (2007). Pengaruh Variabel-Variabel Mikro Variabel-Variabel Makro terhadap Financial Distress pada Perusahaan Industri Food and Beverage yang terdaftar di Bursa Efek Jakarta. Jurnal Aplikasi Manajemen, 5(3), 484-491.

Firmansyah, I., \& Nasrulloh, A. A. (2015). Mengapa Efisiensi Tidak Meningkatkan Kinerja Bank Syariah ? Paper presented at the Forum Riset Ekonomi Keuangan Syariah, Unibraw Malang.

Firmansyah, I., \& Nasrulloh, A. A. (2016). Analisis Stabilitas Efisiensi dan Kinerja Asuransi Syariah dalam Menunjang Pertumbuhan IKNB Syariah. Paper presented at the Forum Riset Ekonomi Keuangan Syariah, IAIN Lampung.

Hidayat, I. P., \& Firmansyah, I. (2017). Financial Distress Analysis Of Islamic Banks In Indonesia. Paper presented at the 3rd International Conference on Economics \& Banking, Lombok Mataram.

Husein, M. F., \& Pambekti, G. T. (2014). Precision of the Models of Altman, Springate, Zmijewski, and Grover for Predicting the Financial Distress. Journal of Economics, Business, and Accountancy Ventura, 17(3), 405-416. 
Imanjadeh, P., Jouri, M. M., \& Sapehri, P. (2011). A Study of the Aplication of Springate and Zmizewski Bankruptcy Prediction Models in Firms Accepted in Tehran Stock Exchange. Australian Journal of Basic and Applied Science, 5(11), 1546-1550.

Irwan. (2017). The Effect of Financial Rations on Islamic Rural Bank Performance in Indonesia. International Journal of Scientific E Technology Research, 6(8).

Jawadi, F., Hachich, N., Fakhfekh, M., \& Cheffou, N. S. A. (2016). Measuring Volatility Persistence for Conventional and Islamic Banks: An FI-EGARCH Approach. Emerging Markets Review.

Komaryatin, N. (2006). Analisis Efisiensi Teknis Industri BPR di Eks Karesidenan Pati. Universitas Dipenogero, Semarang.

Kurniasari, C., \& Ghozali, I. (2013). Analisis Pengaruh Rasio CAMEL dalam Memprediksi Financial Distress Perbankan di Indonesia. Diponegoro Journal of Accounting, 2(4), 1-10.

Mongid, A. (2015). Liquidity Risk Management in the Islamic Rural Banking: Evidence from Indonesia. Bnk and Bank System, 10(3).

Muhammad. (2005). Manajemen Bank Syariah. Yogyakarta: UUP AMPYKPN.

Rahmania, M. F., \& Hermanto, S. B. (2014). Analisis Rasio Keuangan terhadap Financial Distress Perusahaan Perbankan Studi Empiris di BEI 2010-2012. Jurnal Ilmu dan Riset Akuntansi, 3(11), 1-20.

Rahnamai-Roodposhti, F., \& Salehi, A. K. (2010). Financial schools and theories. First Edition. : Science and Research Branch of the Islamic Azad University.

Raza, A. U. (2015). Impact of Financial Distress on the Efficiency of Selected Manufacturing Firm of Ethiopia. Developing Country Studies, 5(19).

Ressy, E. P. (2016). Peran Good Corporate Governance dalam Memoderasi Pengaruh Makro Ekonomi terhadap Financial Distress. (pascasarjana), UNISSULA.

Ruslim. (2012). The Effect of Capital Adequacy Ratio (CAR), Non Performing Loan (NPL) and Loan to Deposit Ratio (LDR) to Return on Asset (ROA) on Islamic bank in Indonesia. Hasanuddin University, Makassar.

Santoso, W. (1996). The Determinants of Problem Banks in Indonesia (An Empirical Study).

Septianto, H., \& Tatik, W. (2010). Analisis Efisiensi Bank Perkreditan Rakyat Di kota Semarang Dengan Pendekatan Data Envolepment Analysis. Media Statistika, 3(1), 41-48.

Setiawan, C., \& Putri, M. E. (2013). Non-Performing Financing and Bank Efficiency of Islamic Banks in Indonesia. Journal of Islamic Finanice and Business Research, 2(1), 58-76.

Smith, J., \& Gunther, I. (2017). Financial Distress in Microcredit Borrowers: Over indebtedness or a Symptom of Poverty? : this research is collected as part of collaborative research project on financial struggling between the Financial Cooperation Independent Evaluation Unit of the KfW Development Bank and ETH Zurich.

Sriyana, J. (2015). Islamic Banks' Profitability AMID the Competitive Financing in Indonesia. IJABER, 13(4), 1695-1710.

Sutawijaya, A., \& Lestari, E. P. (2009). Efisiensi teknik Perbankan Indonesia pascakrisis ekonomi : Sebuah studi empiris penerapan model DEA. Jurnal Ekonomi Pembangunan, 10(1), 49-67. 
Sutrisno. (2016). Risk, Efficiency, and Performance of Islamic Banking: Empirical Study on Islamic Bank in Indonesia. Asian Journal of Economic Modelling, 4(1), 47-56.

Talluri, S. (2000). Data Envelopment Analysis: Models and Extensions. Paper presented at the Decision Line Silberman College of Business Administration, New Jersey.

Tanjung, H., \& Devi, A. (2013). Metodologi Penelitian Ekonomi Islam. Jakarta: Gramata Publishing.

Tarmizi, A., \& Kusuno, W. K. (2003). Analisis Rasio-Rasio Keuangan sebagai Indikator dalam Memprediksi Potensi Kondisi Bermasalah Perbankan di Indonesia. Media Ekonomi dan Bisnis, 15(1).

Tesfamarian, Y. (2014). The Determinants of Financial Distress in the Case of Manufacturing Share Companies in Addis Ababa-Ethiopia. Addis Ababa University, Ethiopia.

Yahhoubnejad, A., \& Sheikhi, K. (2009). A Comparative study of Altman, Zmizewski and Fulmer models in bankruptcy prediction in firms accepted in Tehran Stock Exchage. A Comparative study of Altman, Zmizewski and Fulmer models in bankruptcy prediction in firms accepted in Tehran Stock Exchage.

Zeitun, R. (2012). Determinant of Islamic and conventional banks performance in GCG countries using panel data analysis. Global Economy and Finance Journal, 5(1), 53-72.

Zeitun, R., Tian, G., \& Keen, K. (2007). Default probability for the Jordanian Companies: A Test of Cash Flow Theory. International Research Journal of Finance and Economics, 8. 